\title{
Project-Based Learning Model with A Scientific Approach to Mathematics Learning in Covid-19 Pandemic
}

\author{
Arum Dwi Rahmawati 1, Djoko Hari Supriyanto ${ }^{2}$, Wulan Ria Sari3
}

DOI: $10.35445 /$ alishlah.v13i1. 595

\begin{abstract}
Article Info
Abstract

Keywords:

Project-based learning,

This study aimed to determine the effect of using a project-based learning model Scientific approach Mathematics

with a scientific approach to students' mathematics learning. This kind of examination with experimental methods is included in quantitative research. This research design is a quasi-experiment. Samples were taken from 2 classes, the population in this exam was all class VIII SMP Negeri 3 Ngrambe in the 2020/2021 school year. The method used in sampling is cluster random sampling. Information retrieval procedures in this study using tests and documentation. The method of checking information uses instrument tests, prerequisite tests, and hypothesis testing. The results of information testing with a significant degree of $5 \%$ (0.05), namely the information data on the results of the lilliefors normality test. The learning outcomes of the experimental class $\mathrm{L}$ count $<\mathrm{L}$ table $(0.039<0.173)$, and the control class $\mathrm{L}$ count $<\mathrm{L}$ table (0.031 <0.173). It can be considered that the information data submitted is normal. Based on the information data on the homogeneity test results, pretest information data $\mathrm{F} \max <\mathrm{F}$ table $(1.24<1.98)$. It means that the information was homogeneous. Based on the information data on the results of hypothesis testing, pretest before treatment from the experimental class and the control class got $t$ count $<\mathrm{t}$ table $(-0,501<1,677)$. The statement is likely acknowledged or, as a whole, there is no influence from the project-based model with a projectbased learning model with a scientific approach to students' mathematics learning outcomes Posttest information data obtained by $\mathrm{T}$ count $>\mathrm{T}$ table (3.566> 2.063), in other words, the effect of the project-based learning model on students' mathematics learning outcomes in class VIII SMP Negeri 3 Ngrambe in the academic year 2020/2021.
\end{abstract}

Kata kunci:

Project based learning, Pendekatan saintifik Matematika

\begin{abstract}
Abstrak
Tujuan penelitian ini untuk mengetahui adanya pengaruh penggunaan model project based learning dengan pendekatan saintifik terhadap belajar matematika. Penelitian ini menggunakan metode eksperimen dan termasuk dalam penelitian kuantitatif. Desain penelitian ini adalah quasi ekperimen.
\end{abstract}

\footnotetext{
${ }^{1}$ STKIP Modern Ngawi, Ngawi, Indonesia

Email: arum.dr21@gmail.com

${ }^{2}$ STKIP Modern Ngawi, Ngawi, Indonesia

Email: djoko.hs@gmail.com

3 STKIP Modern Ngawi, Ngawi, Indonesia

Email:wulanriasario7@gmail.com
} 
Sampel diambil dari 2 kelas, populasi dalan ujian ini adalah seluruh kelas VIII SMP Negeri 3 Ngrambe tahun ajaran 2020/2021. Metode pengambilan sampel yaitu cluster random sampling. Prosedur pengambilan informasi dalam penelitian ini menggunakan tes dan dokumentasi. Metode pemerikasanaan informasi menggunakan uji instrumen, uji prasyarat, uji hipotesis. Hasil pengujian informasi dengan derajat besar $5 \%(0,05)$ yaitu dilihat dari data informasi hasil uji normalitas lilliefors, hasil belajar kelas ekperimen L hitung $<$ L tabel $(0,039<0,173)$, dan kelas kontrol L hitung $<$ L tabel $(0,031<0,173)$ dapat dianggap bahwa data informasi yang disampaikan tersebut normal. Berdasarkan data informasi hasil uji homogenitas diperoleh data informasi pretest $\mathrm{F}$ max $<\mathrm{F}$ tabel $(1,24<1,98)$ disimpulkan bahwa informasinya homogen. Data informasi hasil uji hipotesis, prestest sebelum perlakuan dari kelas eksperimen dan kelas kontrol mendapat t hitung < t tabel $(-0,501<1,677)$, sangat mungkin beralasan bahwa penyataan tersebut diakui atau secara keseluruhan "tidak adanya pengaruh dari model project based learning dengan model porject based learning dengan pendakatan saintifik terhadap hasil belajar matematika siswa di kelas VIII SMP Negeri 3 Ngrambe tahun ajaran 2020/2021". Data informasi hasil posttest diperoleh T hitung $>\mathrm{T}$ tabel $(3,566$ $>2,063$ ) sehingga Ho ditolak dan Ha di terima dengan kata lain adanya pengaruh model project based learning (PjBL) terhadap hasil belajar matematika siswadi kelas VIII SMP Negeri 3 Ngrambe tahun ajaran 2020/2021.

\section{PENDAHULUAN}

Pembelajaran yang diterapkan untuk siswa harus memiliki pilihan untuk membangun kompetensi, terutama saat belajar dipengaruhi oleh pandemi virus corona. Mengenai efek pandemi ini, siklus pembelajaran di Indonesia dengan cepat menyesuaikan dengan perubahan yang ada sehingga kerangka pembelajaran dikoordinasikan melalui kerangka kerja jarak jauh yang dikelola melalui kementrian pendidikan dan kebudayaan nomer 4 tahun 2020 tentang pelaksanaan instruksi dalam krisis untuk penyakit covid (virus corona). Ada tiga fokus pengaturan yang diidentifikasi dengan pembelajaran berbasis online/jaruk jauh. Pertama, mencari tahu bagaimana memberikan pencapaian program pendidikan untuk kenaikan kelas dan kelulusan, tanpa terbebani tuntutan untuk menuntaskan. Kedua, cenderung berpusat pada pelatihan kemampuan dasar, termasuk yang berkaitan dengan pandemi virus corona. Ketiga, latihan dan tugas belajar dapat berubah diantara siswa, seperti yang ditunjukkan oleh kelebihan dan kondisi individu mereka, termasuk pemikiran tentang kesenjangan akses/ fasilitas belajar di rumah (Yuliana, 2020).

Arahan selama pandemi virus corona, pendidikan dan pelatihan di hadapkan pada keadaan yang mengharapkan pendidik memiliki pilihan untuk memilih media pembelajaran jarak jauh. Kerangka pelatihan jarak jauh merupakan salah satu jawaban untuk mengatasi tantangan dalam pembelajaran langsung dengan adanya aturan social distanting yang memikirkan masalah waktu, tempat, jarak dan biaya yang menjadi penghalang signifikan saat ini. Pada pembelajaran jarak jauh di rumah, orang tua memiliki tugas penting untuk dilakukan dalam mengamati latihan anak-anak di rumah terumata jika siswa dipersilahkan untuk belajar matematika melalui website. Strategi pembelajaran di era globalosasi saat ini dan pemanfaatan inovasi diperlukan untuk kemajuan media dan pembelajaran penglihatan dan mulitimedia untuk pembelajaran matematika (Abidin, 2020).

Kodir (2018) menjelaskan model pembelajaran berbasis proyek sebagai model pembelajaran yang terfokus pada siklus yang cukup terencana, berpusat pada masalah, mengkoordinasikan ideide dari berbagai bagian informasi atau urutan atau bidang belajar. Dan dari pendapat Prabowo (2013) pembelajaran berbasis proyek ini tidak hanya mengkaji hubungan antara informasi teoritis dan praktek, tetapi juga memotivasi siswa untuk merefleksi apa yang mereka pelajari dalam pembelajaran dalam sebuah proyek nyata. Siswa dapat bekerja secara nyata, seolah olah ada di dunia nyata yang dapat menghasilkan produk secara realistis. Prinsip yang mendasari adalah bahwa 
dengan aktifitas kompleks ini, kebanyakan proses pembelajaran yang terjadi tidak tersusun dengan baik. Pembelajaran berbasis proyek juga dapat meningkatkan keyakinan diri para siswa, memotivasi untuk belajar, kemampuan kreatif, dan mengagumi diri sendiri. Menurut Dahar (2011) target pembelajaran berbasis proyek antara lain meningkatkan kapasitas siswa untuk mengatasi masalah proyek, mengamankan informasi dan kemampuan baru dalam penguasaan, membuat siswa lebih dinamis dalam menangani masalah tugas yang kompleks dengan hasil usaha yang nyata, menciptakan dan meningkatkan kemampuan siswa dalam menyiapkan bahan atau alat untuk menyelesaikan tugas atau usaha untuk mengembangkan usaha bersama siswa, khususnya dalam perkumpulan.

Langkah-langkah pembelajaran menggunakan model project based learning dengan pendekatan saintifik adalah membuka pembelajaran dengan suatu pertanyaan menantang, merencanakan proyek, menyusun jadwal aktivitas, mengawal jalannya tugas/proyek yang diberikan, penilaian terhadap hasil yang sudah di kerjakan, dan evaluasi tugas/proyek (Rais, 2010). Tujuan yang mendasari melakukan pembelajaran berbasis proyek adalah mencirikan misi usaha tergantung pada isu-isu yang diakui dan memutuskan tujuan tugas yang akan dikerjakan. Pendidik menilai siswa berdasarkan kemampuan dasar mereka dan memutuskan batas waktu dalam menyelesaikan tugas. Penilaian dilakukan dengan fasilitas yang diatur untuk pelaksanaan program proyek dan merencanakan strategi dan instrumen penilaian untuk mengevaluasi setiap siswa yang bekerja dalam kelompok (Siwa \& Muderawan, 2013).

Matematika dipandang sebagai salah satu pelajaran penting yang harus dikuasai siswa. Siswa dituntut aktif dalam belajar sehingga akan memiliki pemahaman yang baik (Purbaningsih, 2017). Setelah dilakukan observasi dan wawancara dengan pendidik/guru mata pelajaran matematika, bahwa pembelajaran matematika di SMP Negeri 3 Ngrambe mengalami banyak tantangan dan permasalahan selama pembelajaran online/jarak jauh yang akan mempengaruhi jalannya pembelajaran diantaranya. Pendidik dan siswa terkendala sinyal terutama bagi siswa yang tinggal di pegunungan. Guru melihat sarana dan prasarana yang tidak memadai, siswa berpikir bahwa sulit untuk memahami terlalu banyak topik dalam jangka waktu yang cukup singkat, terutama pelajaran matematika dan IPA. Latihan pada pelajaran ini akan membutuhkan waktu yang cukup lama mengingat banyaknya penurunan rumus atau persamaan artinya.

Penelitian tentang pembelajaran berbasis proyek telah dilakukan oleh peneliti sebelumnya. Rohana (2016) melakukan penelitian tentang penggunaan model PjBL dengan tujuan akhir untuk meningkatkan kemampuan nalar imajinatif dan pemahaman ide pada materi pencemar lingkungan. Desiana (2015) mengkaji tentang penerapan model project based learning dapat meningkatkan aktivitas dan pemahaman konsep siswa kelas X SMA. Utari et al., (2019) dalam penelitiannya menemukan bahwa sebagian besar siswa menganggap sulit dan merasa lelah atau tidak dapat memahami serta berinteraksi dengan baik sehingga pembelajaran matematika kurang maksimal ditunjukkan oleh tidak adanya pengaruhnya terhadap prestasi belajar siswa yang tidak sesuai dengan yang diharapkan. Berbeda dengan penelitian sebelumnya, penelitian ini mengkaji tentang pengaruh penggunaan model project based learning dengan pendekatan saintifik terhadap belajar matematika di masa pandemic ini yang menerapkan sistem belajar online/jarak jauh. Penelitian ini penting dilakukan sebagai pertimbangan dalam memberikan tugas yang sesuai bagi siswa dalam proses belajar selama masa pandemic ini.

\section{METODE}

Penelitian ini dengan metode eksperimen dan termasuk dalam penelitian kuantitatif. penelitian ini dilakukan di SMP Negeri 3 Ngrambe dengan populasi seluruh kelas VIII SMP Negeri 3 Ngrambe. Sampel pada penelitian ini diambil 2 kelas. Kelas pertama terdiri dari 25 siswa sebagai kelas eksperimen yang dikenakan pada model pembelajaran project based learning dengan pendekatan saintifik. Kelas kedua sebagai kelas kontrol dengan jumlah 24 siswa yang tidak 
dikenakan dengan model pembelajaran project based learning dengan pendekatan saintifik. penelitian ini dimulai dari bulan Oktober 2020 hingga Desember 2020.

Penelitian ini menggunakan metode cluster random sampling dalam pemilihan siswa, dimana pengujian tidak hanya mengambil siswa tertentu yang dipilih dan kemudian dikumpulkan ke dalam kelas-kelas khusus (Arikunto, 2016). Meskipun demikian, kelas yang dipilih tergantung pada tujuan yang akan dicapai, khususnya mengetahui dampak penggunaan model pembelajaran project based learning dengan pendekatan saintifik. Strategi pengumpulan informasi dalam penelitian ini menggunakan tes yang digunakan dalam pengujian ini dengan menggunakan 11 butir sooal yang diberikan menggunakan aplikasi google classroom. Tes diberikan sebelum perlakuan (pretest) dan setelah perlakuan (posttest). Tes tersebut digunakan untuk mengukur pemahaman siswa terhadap materi yang kurang dalam pemahaman. Dan selanjutnya bermacam-macam informasi dokumentasi yang diperlukan dalam penelitian ini. Strategi investigasi informasi dalam pemerikasaan ini menggunakan uji nstrumen (uji validitas dan uji reliabilitas), uji prasyarat (uji normalitas dan uji homogenitas), uji hipotesis dengan menggunakan t-test.

\section{HASIL PENELITIAN DAN PEMBAHASAN}

Proses pembelajaran matematika SMP Negeri 3 Ngrambe sebelum dilakukannya penelitian ini masih menggunakan satu arah, materi disampaiakn oleh pendidik kemudian siswa menyimak, dan mendengarkan materi yang disampaikan pendidik dengan tenang. Saat terjadi pandemi covid-19 seperti saat ini, pendidik tidak melakukan pembelajaran secara langsung, namun pembelajaran dilakukan secara online/jarak jauh. Guru melaksanakan pembelajaran menggunakan aplikasi whatsapp, google classroom, e-learning, dll. Buku referensi yang digunakan pada pembelajaran matematika di SMP Negeri 3 Ngrambe siswa hanya menggunakan Lembar Kerja Siswa dan satu buku paket matematika yang di berikan oleh pihak sekolah, sebagai buku pegangan selama proses pembelajaran.

Kondisi sarana dan prasarana pembelajaran matematika di SMP Negeri 3 Ngrambe sudah cukup memadai untuk membantu pembelajaran, di dukung oleh pendidik yang sesuai dengan bidangnya. Namun, pendidik jarang melalukan praktikum dikarenakan keterbatasan waktu, dan kekurangan alat dan bahan yang digunakan untuk praktikum. Demikian pula siswa tidak dikoordinasikan untuk mempelajari lingkungan sebagai sumber belajar. Dalam pembelajaran matematika sebelumnya, pendidik tidak pernah menggunakan model pembelajaran project based learning dengan pendekatan saintifik, yang dapat berpikir secara inovatif, khususnya dalam materi koordinat kartesius, selain itu evaluasi hasil belajar memperkirakan berbagai sudut pandang sebagai retensi. Siswa tidak diberikan kegiatan pengujian seperti mempersiapkan kemampuan berpikir kreatif. Dalam interaksi pembelajaran, guru berpedoman pada standar pembelajaran, tetapi belum memberikan kesempatan pada siswa untuk melakukan percobaan dalam proses pembelajaran.

\section{Penyajian Data Tes Siswa}

Data informasi yang dihitung adalah data informasi hasil belajar kelas eksperimen dan kelas kontrol, sebelum data informasi dihitung menggunakan uji-t, data tersebut di hitung prasyarat analisisnya. Dapat dilihat sebagai berikut ini:

\section{Tabel 1. Data Pretest Kelas Eksperimen dan Kelas Kontrol}

\begin{tabular}{lcc}
\hline Statistik & Ekperimen & Kontrol \\
\hline N (jumlah siswa) & 25 & 24 \\
Jumlah nilai & & 1142 \\
Rata-rata & 1006 & 47,48 \\
Varians & 42,64 & 1.015 \\
Standar Deviasi & 1.322 & 32,539 \\
Maksimum & 36,371 & 88 \\
Minimum & 100 & 0 \\
& 0 & \\
\hline
\end{tabular}


Pada tabel terlihat hasil pengolahan data informasi pretest dari kelas eksperimen dan kelas kontrol. Sebelum kelas eksperimen diberikan perlakuan model pembelajaran project based learning dengan pendekatan saintifik, terlebih dahulu kelas eksperimen dan kelas kontrol dilakukan uji coba awal (pretest) bertujuan untuk mengetahui kemampuan atau pencapaian pemahaman awal. Pada tabel di atas data informasi pretest kelas eksperimen dengan jumlah 25 siswa dengan jumlah nilai 1006, rata-rata nilai 42,64, nilai varian 1.322, dengan standar deviasi 36, 371, dan nilai tertinggi yang diperoleh adalah 100. Untuk data informasi pretest kelas kontrol dengan jumlah siswa 24, dengan jumlah nilai 1142, rata-rata nilai 47,48, nilai varian 1.015, dengan standar deviasi 32,539, dan nilai tertinggi adalah 88 .

\section{Tabel 2. Data Posttest Kelas Eksperimen dan Kelas Kontrol}

\begin{tabular}{lcc}
\hline Statistik & Ekperimen & Kontrol \\
\hline N (jumlah siswa) & 25 & 24 \\
Jumlah nilai & 2200 & 1300 \\
Rata-rata & 88 & 54,16 \\
Varians & 1100 & 791,97 \\
Standar Deviasi & 33,166 & 28,747 \\
Maksimum & 100 & 88 \\
Minimum & 0 & 8
\end{tabular}

Pada tabel terlihat hasil pengolahan data informasi posttest dari kelas eksperimen dan kelas kontrol. Setelah kelas eksperimen yang dipaparkan atau diberikan perlakuan model pembelajaran project based learning dengan pendekatan saintifik, kelas eksperimen dan kelas kontrol dilakukan uji coba akhir (posttest) bertujuan untuk mengetahui pencapaian pemahaman akhir. Pada tabel di atas data informasi postest kelas eksperimen dengan jumlah 25 siswa dengan jumlah nilai 2200, rata-rata nilai 88 , nilai varian 1100 , dengan standar deviasi 33,166 , dan nilai tertinggi yang diperoleh adalah 100. Untuk data informasi posttest kelas kontrol dengan jumlah 24 siswa, dengan jumlah nilai 1300 , rata-rata nilai 54,16, nilai varian 791,97, dengan standar deviasi 28,747 , dan nilai tertinggi adalah 88.

Berikut data informasi hasil perhitungan manual untuk uji normalitas, uji homogenitas, dan uji hipotesis.

a. Uji Normalitas data informasi hasil kelas eksperimen dan kelas kontrol dilakukan untuk melihat apakah data tersebut normal atau tidak normal. Pengujian ini menggunakan rumus lilliefors secara manual, dapat dilihat sebagai berikut:

Tabel 3. Data Hasil Perhitungan Manual Uji Normalitas

\begin{tabular}{llccc}
\hline \multicolumn{1}{c}{ Kelas } & $\begin{array}{c}\text { L hitung } \\
\text { pretest }\end{array}$ & $\begin{array}{c}\text { L hitung } \\
\text { Posttest }\end{array}$ & L tabel & Keterangan \\
\hline Ekperimen & 0,034 & 0,039 & 0,173 & Normal \\
Kontrol & 0,031 & 0.031 & 0,173 & Normal
\end{tabular}

Data informasi hasil perhitungan dapat disimpulkan untuk kelas eksperimen dengan jumlah siswa 25 dengan taraf signifikan 5\% (0,05) hasil pretest bahwa L hitung < L tabel $(0,034<$ o,173), maka dapat dikatakan data tersebut normal. Untuk kelas eksperimen hasil posttest bahwa L hitung < L tabel $(0,031<0,173)$, maka dapat dikatakan data tersebut normal. Data informasi hasil perhitungan dapat disimpulkan untuk kelas kontrol dengan jumlah siswa 24 dengan taraf signifikan $5 \%(0,05)$ hasil pretest bahwa L hitung $<$ L tabel $(0,039<0,173)$, maka dapat dikatakan data tersebut normal. Untuk kelas kontrol hasil posttest bahwa L hitung $<\mathrm{L}$ tabel $(0,031<0,173)$, maka dapat dikatakan data tersebut normal.

b. Uji Homogenitas data informasi hasil perhitungan dilakukan untuk mengetahui kelas eksperimen dan kelas kontrol berasal dari populasi yang homogen. perhitungan uji homogenitas dilukukan secara manual. Dapat dilihat sebagai berikut: 
Tabel 4. Data Hasil Perhitungan Manual Uji Homogenitas

\begin{tabular}{cccc}
\hline Data & F hitung & F tabel & Keterangan \\
\hline Pretest & 1,24 & 1.98 & Homogen \\
Posttest & 1,42 & 1.98 & Homogen
\end{tabular}

Hasil perhitungan manual yang dilakukan pada data informasi hasil pretest bahwa $\mathrm{F}$ hitung < F tabel $(1,24<1,98)$ dengan taraf signifikan $5 \%(0,05)$ dapat di simpulkan data tersebut homogen. Hasil perhitungan manual yang dilakukan pada data informasi hasil posttest bahwa $\mathrm{F}$ hitung $<\mathrm{F}$ tabel $(1,24<1,98)$ dengan taraf signifikan $5 \%(0,05)$ dapat di simpulkan data tersebut homogen.

c. Uji Hipotesis menggunakan uji - t (uji two $t$-test), perhitungan uji hipotesis secara manual, dapat dilihat sebagai berikut:

Tabel 5. Data Hasil Perhitungan Manual Uji Hipotesis

\begin{tabular}{cccc}
\hline Kelas & T hitung & T tabel & Keterangan \\
\hline Pretest & $-0,501$ & 2,063 & Ditolak \\
Posttest & 3,566 & 2,063 & Diterima
\end{tabular}

Berdasarkan data informasi hasil pretest dan posttest seperti diatas, hasil pretest diperoleh $\mathrm{T}$ hitung $<$ T tabel $(-0,501<2,063)$ dengan kata lain "tidak ada pengaruh model project based learning dengan pendekatan saintifik terhadap hasil belajar matematika siswa”.

Hasil penelitian di atas menjadi dasar yakni hasil posttest diperoleh $\mathrm{T}$ hitung $>\mathrm{T}$ tabel ( 3,566 $>2,063$ ) sehingga Ho ditolak dan Ha di terima dengan kata lain "adanya pengaruh model project based learning terhadap hasil belajar matematika siswa". Penelitian ini sejalan dengan hasil penelitian oleh (Aminullah, 2018) dengan hasil penelitian menunjukkan bahwa model PjBL memberikan pengaruh yaitu perbedaan hasil setelah dilakukan dengan penggunaan model $\mathrm{PjBL}$ pada kelas kontrol, rata-rata nilai kemampuan siswa dalah 65,44 dibahwa nilai normal kelas ekperimen adalah 84,67. Kemudian hasil penelitian ini juga di dukung oleh Utami et al., (2015) tentang pengaruh model project based learning berbantu instagram terhadap keterampilan berpikir kreatif pada materi pencemaran lingkungan. Pada penelitian ini terdapat perbedaan hasil setelah diberi perlakuan menggunakan model project based learning. Pada kelas kontrol rata-rata nilai ketrampilan siswa 77,12 dan pada kelas eksperimen adalah 82,72. Penelitian lain yang di lakukan oleh (Wahyulianti, 2015) yang bertujuan untuk meningkatkan kreativitas dan hasil belajar siswa kelas XI, dengan hasil penelitian menunjukkan presentase kelas kreativitas sebelum diberi perlakuan sebesar $65,61 \%$. Setelah diberi perlakuan presentase kelas kreativitas meningkat menjadi $89,39 \%$.

Penelitian ini terjadi peningkatan hasil belajar, pemahaman materi yang cukup baik terhadap materi yang di berikan, dan antusias siswa terhadap penggunaan model project based learning dengan pedekatan saintifik, siswa cenderung lebih aktif untuk bertanya dan mengerjakan tugas/proyek yang diberikan melalui google classroom. Dapat dilihat dari hasil belajar siswa mengalami peningkatan yang cukup signifikan dibanding sebelum diberikan perlakuan penggunaan model project based learning dengan pendekatan saintifik.

\section{SIMPULAN}

Model project based learning dengan pendekatan saintifik merupakan pilihan yang tepat dalam proses belajar di masa pandemic ini. Berdasarkan hasil penelitian ini, terjadi peningkatan hasil belajar dan antusias siswa terhadap penggunaan model project based learning dengan pedekatan saintifik. Siswa cenderung lebih aktif untuk bertanya dan mengerjakan tugas/proyek yang diberikan melalui google classroom dibandingkan tugas/pemberian materi saja. Dilihat dari data 
informasi hasil posttest diperoleh posttest diperoleh T hitung > T tabel ( 3,566 > 2,063) sehingga Ho ditolak dan Ha di terima dengan kata lain adanya pengaruh model project based learning terhadap hasil belajar matematika siswa di kelas VIII SMP Negeri 3 Ngrambe tahun ajaran 2020/2021. Penelitian ini dapat dijadikan sebagai rujukan dalam pemilihan metode pembelajaran pada masa pandemic yang menerapkan pembelajaran jarak jauh.

\section{DAFTAR PUSTAKA}

Abidin, Z. (2020). Belajar Matematika di Era Covid-19. OSF Pre-print. Vol. 1(2). https://doi.org/10.31219/osf.io/nrbu7

Aminullah, A. (2018). Kajian Penggunaan Metode Pembelajaran Berbasis Proyek (Project Based Learning) Dalam Meningkatkan Kemampuan Berpikir Kreatif Matematis. Prosiding Seminar Nasional Pendidik Dan Pengembang Pendidikan Indonesia, 43-51.

Anis, A., \& Puspitasari, Y. D. (2020). Penerapan Model Pembelajaran Pjbl Dengan Google Classroom Untuk Meningkatkan Hasil Belajar Siswa Pada Mata PELAJARAN IPA. Papua Journal of Physics Education, 1(2), 1-12.

Arikunto, S. (2016). Dasar-dasar evaluasi pendidikan. Jakarta : Alfabeta

Dahar, R. W. (2011). Teori-teori belajar dan pembelajaran. Jakarta: Erlangga, 136, 141.

Desiana, R. (2015). Keefektifan model project based learning berbasis video pada pembelajaran fisika untuk meningkatkan aktivitas dan pemahaman konsep siswa. Universitas Negeri Semarang.

Hosnan, M. (2014). Pendekatan saintifik dan kontekstual dalam pembelajaran abad 21: Kunci sukses implementasi kurikulum 2013. Bogor: GhaliaIndonesia.

Kodir, A. (2018). Manajemen Pembelajaran Saintifik Kurikulum 2013: Pembelajaran Berpusat pada Siswa. Pustaka Setia.

Prabowo, A. (2013). Pembelajaran berbasis proyek untuk meningkatkan pemahaman mahasiswa atas permasalahan statistika pada perkuliahan studi kasus dan seminar. Kreano, Jurnal Matematika Kreatif-Inovatif, 3(2), 82-90.

Purbaningsih, T. (2017). Penggunaan Alat Peraga Untuk Meningkatkan Motivasi dan Hasil Belajar Matematika Siswa Kelas IV SD Negeri o3 Gondangrejo Tahun Pelajaran 2017. IAIN Metro.

Rais, M. (2010). Project based learning: inovasi pembelajaran yang berorientasi soft skills. Proseding Seminar Nasional Pendidikan Teknologi Dan Kejuruan Fakultas Teknik Universitas Negeri Surabaya.

Rohana, R. S. (2016). Penerapan Model Project Based Learning Dalam Upaya Meningkatkan Kemampuan Berpikir Kreatif Dan Penguasaan Konsep Peserta Didik Pada Materi Pencemaran Lingkungan. Prosiding Seminar Nasional Inovasi Pendidikan.

Siwa, I. B., \& Muderawan, I. W. (2013). Pengaruh pembelajaran Berbasis Proyek dalam Pembelajaran Kimia terhadap Keterampilan Proses Sains ditinjau dari gaya kognitif siswa. Jurnal Pendidikan Dan Pembelajaran IPA Indonesia, 3(2).

Sugiyono. (2008). Metode penelitian pendidikan:(pendekatan kuantitatif, kualitatif dan $R \& D$ ). Alfabeta.

Utami, R. P., Probosari, R. M., \& Fatmawati, U. M. I. (2015). Pengaruh Model Pembelajaran Project Based Learning Berbantu Instagram Terhadap Kemampuan Berpikir Kreatif Siswa Kelas X SMA Negeri 8 Surakarta. Bio-Pedagogi, 4(1), 47-52.

Utari, D. R., Wardana, M. Y. S., \& Damayani, A. T. (2019). Analisis Kesulitan Belajar Matematika dalam Menyelesaikan Soal Cerita. Jurnal Ilmiah Sekolah Dasar, 3(4), 534-540. https://doi.org/10.23887/jisd.v3i4.22311

Wena, M. (2009). Strategi pembelajaran inovatif kontemporer suatu tinjauan konseptual operasional. Jakarta: Bumi Aksara.

Wiyanto, W. (2017). Pendekatan saintifik pada perkuliahan dengan sistem e-learning. Integralistik, 28(2), 217-229.

Yuliana, C. (2020). Project based learning, model pembelajaran bermakna di masa pandemi covid 19. LPMP Lampung, 1-10. 